\section{Profile of antiretroviral and its outcome on patients with HIV-AIDS in Wamena Public Hospital}

\author{
Erwin Astha Triyono, ${ }^{1}$ \\ Stefania Rany Seran, ${ }^{2}$ Didik Hasmono ${ }^{3}$ \\ ${ }^{1}$ Department of Internal Medicine, \\ Soetomo Hospital Teaching, Surabaya; \\ ${ }^{2}$ Magister of Pharmacy Clinic Programs \\ student, Airlangga University, \\ Surabaya; ${ }^{3}$ Clinical Pharmacy \\ Department, Faculty of Pharmacy, \\ Airlangga University, Surabaya, \\ Indonesia
}

\begin{abstract}
In Papua, HIV/AIDS is characterized as a widespread epidemic, with a prevalence of $2.3 \%$ and a case rate of 416.91 per 100.000. The low accessibility of healthcare services is a major challenge for health services in Papua. The purpose of this study was to determine the profile of ARV use and therapy outcomes of HIV/AIDS patients at Wamena Public Hospital in Papua. This research is an observational cross-sectional retrospective study. Data was collected from the medical records of 236 patients who met the inclusion criteria. Study showed that FDC (TDF + 3TC + EFV) is the most frequently used ARV. ARV therapy improved the clinical condition of 14 patients, and 9 patients had a worsening of their clinical condition. There was an increase in CD4 cell count after 6, 12, and 24 months of ARV therapy in $76 \% ; 55 \%$; and $72 \%$ of patients. There were 55 adverse drug events that required a change of regimen. Based on this study, the use of antiretroviral drugs improved clinical condition, decreasing the number of IO, and increasing the patient's CD4 cell count.
\end{abstract}

\section{Introduction}

Acquired Immune Deficiency Syndrome (AIDS), caused by infection of human immunodeficiency virus (HIV), is a collection of fatal syndromes that, due to progressive damage to the immune system,leaves humans very susceptible to becoming infected with certain diseases. ${ }^{1}$ $\mathrm{HIV}$ is a retrovirus that infects cells that have Cluster of Differentiation 4 (CD4) molecules primarily $\mathrm{T}$ lymphocytes. Retroviruses have the Reverse Transcriptase enzyme that is capable of converting viral RNA to DNA. ${ }^{2}$
Most areas in Indonesia are included in the category of areas with a concentrated HIV epidemic rate with an average prevalence of $0.4 \%$. Papua has entered a widespread epidemic rate with a prevalence of $2.3 \%$ and the case rate in 2016 was 416.91 which far exceeds the national case rate of 28.45. ${ }^{3,4}$ Papua has the highest cumulative rate of AIDS cases in Indonesia after DKI Jakarta. The cumulative cases of HIV infections in Papua up to September 2016 reached 23,450 cases, while the number of AIDS cases reached 13,335 people with deaths from AIDS as many as 1,142 cases. ${ }^{3}$

The number of HIV cases in Jayawijaya in 2016 reached 329 and the cumulative number of AIDS cases by December 2016 reached $1,769 .{ }^{3}$ There were 979 active HIVAIDS patients in Jayawijaya. Wamena Regional Hospital (RSUD) in January 2017 served 215 active HIV / AIDS patients from a total of 640 patients who have visited VCT in the period 2008-2016.

Jayawijaya regency is one of the regencies in the central mountainous region; its mountainous and hilly topography make it difficult for health workers and local community to access health services. The low level of community education, the lack of human resources in health, the limited health facilities, the limited public financing of the health facilities, and the low public awareness of health checks becomes a challenge faced by health services in Jayawijaya.

The increasing number of patients, the number of opportunistic infections (OI) in the patient, the questionable level of patient adherence, the high mortality rate of patients in Papua and the lack of research on the use of antiretroviral drugs in Papua has compelled researchers to examine the picture of ARV use and therapy outcome from ARV use in RSUD Wamena Papua between 2015 and 2017.

\section{Materials and Methods}

This descriptive research is an observational study cross-sectional retrospective. Data were collected for three months between September and November 2017 from adult outpatients diagnosed with HIV / AIDS at RSUD Wamena who met the inclusion criteria. The inclusion criteria specified that subjects must be adult patients ( $\geq 18$ years) at the time of therapy, who had received therapy in April 2015April 2017, and who had undergone at least six months of therapy by April 2017. Pregnant and lactating patients were excluded from the study. An ethical test has been conducted by the Ethics Committee of
Correspondence: Erwin Astha Triyono, Department of internal medicine of Soetomo Hospital Teaching, Jl. Mayjen. Prof. Dr. Moestopo, No. 47, Airlangga, Gubeng, Surabaya, Jawa Timur, Surabaya.

Phone: 08123259941

E-mail: erwintriyono@yahoo.com

Key words: HIV/AIDS, antiretroviral, outcome therapy, CD4 count, hospital.

Contributions: EAT, SRS, DH, data collecting and analyzing; SRS, DH, manuscript writing; EAT, manu- script reviewing and references search.

Acknowledgments: Special thanks to all of the HIV/AIDS patients in RSUD Wamena

Conflict of interest: the authors declare no potential conflict of interest.

Received for publication: 1 February 2019. Accepted for publication: 13 February 2019.

This work is licensed under a Creative Commons Attribution-NonCommercial 4.0 International License (CC BY-NC 4.0).

(C) Copyright E.A. Triyono et al., 2019

Licensee PAGEPress, Italy

Dermatology Reports 2019; 11(s1):8063

doi:10.4081/dr.2019.8063

Faculty of Medicine Airlangga University Surabaya.

This study used patient Document Record (DRM) data, auxiliary data excel, data collection sheets (LDP), and Book Register for Antiretroviral Therapy. All patient data from excel aids \& DRM were recorded in LDP. Data was obtained, analyzed descriptively and presented in table form with frequency calculations. Data analysis was performed on several aspects including the description of antiretroviral treatment, the outcome of antiretroviral therapy (i.e. the development of patient clinical condition, CD4 progression, and development of OI), and the compatibility of antiretroviral therapy used with guidelines for the treatment of HIV/AIDS.

\section{Results}

The characteristics of 236 patients were shown in Table 1 . There were more male patient (128) than women (108).

The number of male patients (128) more than women (108) with the most patients was in the 18-29 age range of 146 $(62 \%)$. As many as $66 \%$ of the status has been married and $75 \%$ of patients have worked. 
There are three classes and ten different combinations of antiretroviral drugs administered to patients with the most widely used therapeutic regimen being TDF (300) $+3 \mathrm{TC}(300)+$ EFV (600) (Table 2).

WHO divides HIV infection rates in four stages: Stage I, II, III and IV. Based on the results of the study, most patients were in clinical stage III (Table 3).

Data obtained in this study indicate that not all patients perform a CD4 examination. Only 120 patients had pre-therapy CD4 cell counts, 41 patients, 83 patients, 81 patients, 54 patients and 89 patients examined at 6 , 12, 24.66 months after therapy and in April 2017. Most patients in the study $(59.15 \%)$ had an initial CD4 cell count $<50$ cells $/ \mathrm{mm}^{3}$ (Table 4).

The results showed that the most frequent opportunistic infections in HIVAIDS patients were diarrhea and oral candidiasis.

In this study, there were 55 incidence of antiretroviral side effects in which there were patients who experienced more than one drug side effect (Table 5).

\section{Discussion}

The principle of antiretroviral therapy is that it should use three types of drugs, all three of which must be absorbed in therapeutic doses in the blood; this is known as highly active antiretroviral therapy (HAART). The term HAART is often shortened to ART (antiretroviral therapy) or ARV therapy. ${ }^{4}$ The study of L. Annison et al in $2013^{5}$ showed that in patients receiving ARV initiation there was an increase in CD4 cell count and a greater chance of immune restoration during the 12 months of treatment.

The results showed that there were three classes and ten different combinations of antiretroviral drugs administered to patients with the most widely used regimen being Triple FDC. KDT was selected because it can improve patient compliance, facilitate patients in taking antiretrovirals, and reduce the risk of side effects. A study in Thailand concluded that the use of FDC proved to be effective and well tolerated. ${ }^{6}$ The regimen of antiretroviral doses received by HIV / AIDS patients was in conformity with existing guidelines such as Guidelines for the Use of Antiretroviral Agents in HIV-1Infected Adults and Adolescents issued by WHO and Antiretroviral Treatment Guidelines by the Ministry of Health of the Republic of Indonesia.

Screening of HIV infection is important, as infected patients can remain asymptomatic for many years. Clinical staging is necessary to determine the gravity of the HIV infection, especially when initiating antiretroviral therapy and changing treatment if a CD4 test can not be performed(7). Of the HIV / AIDS patients at RSUD Wamena at the beginning of therapy 64\% patient had clinical Stage 3 because there were more than two clinical symptoms and opportunistic infections such as diarrhea, candidiasis, and pulmonary TB present in patients. It can be seen in Table 3 that as many as 12 patient had improved clinical conditions in which the IO appeared to be

Table 2. ARV regimen used in patients.

\begin{tabular}{llcccc} 
Code & REGIMFN & \multicolumn{2}{c}{ Early therapy } & \multicolumn{2}{c}{ Until 17-Apr } \\
& & $\sum$ & $\%$ & & $\%$ \\
1 & $\mathrm{~d} 4 \mathrm{~T}(30)+3 \mathrm{TC}(150)+\mathrm{EFV}(600)$ & 2 & 1 & & \\
2 & $\mathrm{~d} 4 \mathrm{~T}(30)+3 \mathrm{TC}(150)+\mathrm{NVP}(200)$ & 4 & 2 & & \\
\hline 3 & $\mathrm{TDF}(300)+3 \mathrm{TC}(150)+\mathrm{EFV}(600)$ & 41 & 17 & 27 & 16 \\
4 & $\mathrm{TDF}(300)+3 \mathrm{TC}(150)+\mathrm{NVP}(200)$ & 2 & 1 & 6 & 4 \\
\hline 5 & $\mathrm{TDF}(300)+3 \mathrm{TC}(300)+\mathrm{EFV}(600)$ & 79 & 33 & 59 & 35 \\
6 & $\mathrm{TDF}(300)+\mathrm{FTC}(200)+\mathrm{EFV}(600)$ & 51 & 22 & 34 & 20 \\
\hline 7 & $\mathrm{TDF}(300)+\mathrm{FTC}(200)+\mathrm{NVP}(200)$ & 2 & 1 & 5 & 3 \\
8 & $\mathrm{ZDV}(300)+3 \mathrm{TC}(150)+\mathrm{EFV}(600)$ & 27 & 11 & 17 & 10 \\
\hline 9 & $\mathrm{ZDV}(300)+3 \mathrm{TC}(150)+\mathrm{NVP}(200)$ & 28 & 12 & 19 & 11 \\
10 & $\mathrm{TDF}(300)+\mathrm{FTC}(200)+\mathrm{LPV} / \mathrm{r}(200 / 50)$ & & & 1 & 1 \\
\hline 11 & $\mathrm{TDF}(300)+3 \mathrm{TC}(150)+\mathrm{LPV} / \mathrm{r}(200 / 50)$ & 236 & 100 & 168 & 100 \\
\hline
\end{tabular}

Table 1. Characteristics of HIV / AIDS patients.

\begin{tabular}{llcc} 
Variable & Type & $\sum$ & $\%$ \\
Total Sample & & 236 & \\
Sex & Male & 128 & 54 \\
& Female & 108 & 46 \\
\hline Age & $18-29$ & 146 & 62 \\
& $30-41$ & 71 & 30 \\
& $42-54$ & 17 & 7 \\
& $55-65$ & 2 & 1 \\
Education & Uneducated & 32 & 14 \\
& Primary school & 34 & 14 \\
& Junior high school & 34 & 14 \\
& Senior High School & 86 & 36 \\
& Academy & 39 & 17 \\
& College & 11 & 5 \\
\hline Marital status & Married & 155 & 66 \\
& Single & 55 & 23 \\
& Widow/widower & 26 & 11 \\
Risk factor & Drug used & 1 & $0 \%$ \\
& Blood transfusion & 1 & $0 \%$ \\
& Heterosecsual & 234 & $99 \%$ \\
& *Free sex behavior & 158 & $68 \%$ \\
\hline Profesion & Employee & 176 & $75 \%$ \\
& Unemployed & 60 & $25 \%$ \\
\hline
\end{tabular}

Table 3. The clinical stages of the patient at pre-therapy until April 31, 2017.

\begin{tabular}{|c|c|c|c|c|c|c|c|c|c|c|}
\hline NO & Type & Pre $t$ & erapy & $\begin{array}{c}6 \\
\text { (month) }\end{array}$ & $\begin{array}{c}12 \\
\text { (month) }\end{array}$ & $\begin{array}{c}24 \\
\text { (month) }\end{array}$ & $\begin{array}{c}36 \\
\text { (month) }\end{array}$ & $\begin{array}{c}48 \\
\text { (month) }\end{array}$ & $\begin{array}{c}60 \\
\text { (month) }\end{array}$ & $\begin{array}{l}\text { Until } \\
\text { 17-Apr }\end{array}$ \\
\hline & & $\sum$ & $\%$ & $\sum \quad \%$ & $\sum \quad \%$ & $\sum \quad \%$ & $\sum \quad \%$ & $\sum \quad \%$ & $\sum \quad \%$ & $\sum \quad \%$ \\
\hline & Total patient & 236 & & 235 & 223 & 199 & 190 & 177 & 172 & 168 \\
\hline & Grade 1 & 37 & & 40 & 38 & 35 & 27 & 15 & 7 & 21 \\
\hline & Grade 2 & 16 & & 20 & 26 & 25 & 24 & 18 & 12 & 25 \\
\hline & Grade 3 & 154 & & 148 & 124 & 89 & 61 & 44 & 35 & 100 \\
\hline & Grade 4 & 29 & & 27 & 22 & 18 & 12 & 10 & 8 & 22 \\
\hline & Lost to Follow up (LFU) & - & & - & 7 & 23 & 33 & 40 & 42 & 42 \\
\hline & Dropped medicine & & & 1 & 1 & 2 & - & - & - & - \\
\hline & Refer out & & & & 4 & 7 & 7 & 13 & 13 & 13 \\
\hline & Death & & & & 1 & 5 & 6 & 9 & 9 & 13 \\
\hline
\end{tabular}


Table 4. Patient's CD4 cell count.

\begin{tabular}{|c|c|c|c|c|c|c|c|c|}
\hline NO Type & Pre therapy & $\begin{array}{c}6 \\
\text { (month) }\end{array}$ & $\begin{array}{c}12 \\
\text { (month) }\end{array}$ & (month) & $\begin{array}{c}36 \\
\text { (month) }\end{array}$ & $\begin{array}{c}48 \\
\text { (month) }\end{array}$ & $\begin{array}{c}60 \\
\text { (month) }\end{array}$ & $\begin{array}{l}\text { Until } \\
\text { 17-Apr }\end{array}$ \\
\hline & $\sum \quad \%$ & $\sum \quad \%$ & $\sum \quad \%$ & $\sum \quad \%$ & $\sum \quad \%$ & & & \\
\hline Total of Patient & 236 & 235 & 223 & 199 & 190 & 177 & 172 & 168 \\
\hline $\mathrm{Cd} 4<50$ & 30 & - & - & 1 & 1 & - & - & - \\
\hline Cd4 50-199 & 46 & 26 & 24 & 10 & 7 & 1 & 1 & 61 \\
\hline Cd4 200-349 & 38 & 11 & 38 & 40 & 19 & 6 & 5 & 25 \\
\hline Cd4 350-500 & 4 & 3 & 13 & 18 & 14 & 17 & 8 & 18 \\
\hline $\mathrm{Cd} 4>500$ & 2 & 1 & 8 & 12 & 13 & 11 & 7 & 38 \\
\hline Undergoing examination & 120 & 41 & 83 & 81 & 54 & 35 & 21 & 89 \\
\hline Don't & 116 & 194 & 140 & 118 & 136 & 142 & 151 & 79 \\
\hline CD4 rise than before therapy & & 17 & 20 & 25 & 18 & 11 & 15 & 38 \\
\hline Decreased CD4 than before therapy & & & 1 & - & 1 & & & - \\
\hline $\begin{array}{l}\text { Cd4 remained unchanged prior } \\
\text { to therapy }\end{array}$ & & 14 & 15 & 15 & & & 2 & 9 \\
\hline $\begin{array}{l}\text { Cd4 Increased compared } \\
\text { to the previous examination period }\end{array}$ & & 17 & 27 & 58 & 40 & 35 & 21 & 51 \\
\hline $\begin{array}{l}\text { Cd4 remains compared to the } \\
\text { previous examination period }\end{array}$ & & 14 & 11 & 11 & & & 3 & 29 \\
\hline $\begin{array}{l}\text { Cd4 decreased compared to the } \\
\text { previous examination period }\end{array}$ & & & - & & & & 1 & 6 \\
\hline $\begin{array}{l}\text { Patient who do not perform } \\
\text { the examination }\end{array}$ & 116 & 194 & 140 & 118 & 136 & 142 & 151 & 79 \\
\hline Have not reached the checking time & - & - & 13 & 32 & 66 & 90 & 110 & \\
\hline Lost to Follow up (LFU) & & & 7 & 23 & 7 & 13 & 13 & 13 \\
\hline Dropped medicine & & 1 & 1 & 2 & & & & \\
\hline Refer out & & & 4 & 7 & 7 & 13 & 13 & 13 \\
\hline Death & & & 1 & 5 & 6 & 6 & 9 & 13 \\
\hline
\end{tabular}

reduced and the patient's CD4 value increased. There are five patients who experienced worsening clinical condition even to death. Examples of this were patients number 4 and number 9 have decreased clinical conditions 48 months after antiretroviral use, due to adverse drug side effects and recurrent opportunistic infections. Patient number 55 went from clinical Stages 3 to 4 as the patient briefly dropped the drug for 2 months and the patient's compliance level was low $(<80 \%)$. The patient was admitted to hospital (MRS) because of recurrent diarrhea for two months and the patient also had esophageal candidiasis. From the data obtained patient number 5 was reclassified from Stage 2 to 3 because the patient had repeated IOs such as diarrhea and candidiasis. Patients also suffered from pulmonary $\mathrm{TB}$ and in the first 12 months of taking ARV, some patients forgot to take their medication.

HIV infects cells using a CD4 molecule as a receptor. CD4 cell count is a way of assessing the immune status of PLWHA. CD4 examination completes clinical examination to determine which patients require prophylactic treatment of OI and ARV ther-

Table 5. Side effect of ARV in HIV/AIDS patients.

\begin{tabular}{|c|c|c|c|}
\hline ARV & Side effect & $\sum$ & $\%$ \\
\hline Efavirenz & $\begin{array}{l}\text { Gynaecomastia } \\
\text { Great Headache }\end{array}$ & $\begin{array}{l}4 \\
4\end{array}$ & $\begin{array}{l}7 \\
7\end{array}$ \\
\hline Zidovudin & $\begin{array}{l}\text { Headache } \\
\text { Anemia }\end{array}$ & $\begin{array}{l}11 \\
16\end{array}$ & $\begin{array}{l}20 \\
29\end{array}$ \\
\hline Stavudin & Peripheral neuropathy & 9 & 16 \\
\hline Nevirapine & $\begin{array}{l}\text { Skin Rash } \\
\text { Stevens-Johnson syndrome } \\
\text { Ichteric } \\
\text { Drug induce hepatitis }\end{array}$ & $\begin{array}{l}1 \\
1 \\
5 \\
2\end{array}$ & $\begin{array}{l}2 \\
2 \\
9 \\
4\end{array}$ \\
\hline Tenofovir & $\begin{array}{l}\text { Nausea vomiting } \\
\text { Kidney disorder } \\
\text { Total }\end{array}$ & $\begin{array}{c}1 \\
1 \\
55\end{array}$ & $\begin{array}{c}2 \\
2 \\
100\end{array}$ \\
\hline
\end{tabular}

*Patients experience more than one type of drug side effects.

apy. ${ }^{7}$ In healthy individuals normal, CD4 cell count is 800 to 1000 cells $/ \mathrm{mm}^{3}{ }^{8}$ Mean CD4 decline was about 70-100 cells $/ \mathrm{mm}^{3}$ / year, with an increase after ARV treatment of between $50-100$ cells $/ \mathrm{mm}^{3} /$ year. $^{7}$

According to the literature, examination of CD4 count is indispensable in the treatment of HIV / AIDS. However, because the epidemiological rate of HIV transmission in
Papua has entered a widespread epidemiological level then ARV treatment can be performed regardless of clinical condition and patient's CD4 value. Before therapy, only 120 patients had CD4 cell counts in which $76(63 \%)$ were immunodeficient (30 patients had baseline CD4 cell count $<50$ cells $/ \mathrm{mm}^{3}$ and 46 patients had CD4 cell count 50-199 cells $/ \mathrm{mm}^{3}$ ). 
The data indicated a patient's CD4 cell count increased; whereas in the 6th month there were only 17 patients of whom this was true, at 12th, 24th, and 36th month until the end of April 2017 there were 20, 25, 18 and 38 patients whose CD4 values were increased compared to before therapy. Only one patient (number 52) had decreased CD4 cell counts after 6 months of therapy; this was due to poor adherence $(<80 \%)$. Another patient also had decreased CD 4 cell count at month 36, due to a drug break for a year. Changes in CD4 values were also seen in each examination period in which 17 , $27,58,40$ and 51 patients had an increase in CD4 cell count at $6,12,24$, and 36 months after therapy until April 2017. A total of 14, 11 , and 11 patients at month 6,12 , and 24 managed to keep their CD4 values fixed in the previous examination period.

In the group of patients with baseline CD4 cell count $<50$ cells $/ \mathrm{mm}^{3}$, there were two patients who had significant CD4 cell gain from $<50$ cells $/ \mathrm{mm}^{3}$ to above 500 cells $/ \mathrm{mm}^{3}$ in April 2017, i.e patients 61 and 105. A study in Botswana reported that a significant CD4 increase in patients with an initial CD4 cell count $<200$ cells $/ \mathrm{mm}^{3} .{ }^{9}$ Three patients with CD4 $<50$ cells $/ \mathrm{mm}^{3}$ died after 12-24 months of antiretroviral therapy due to hepatitis, toxoplasmosis and decreased consciousness. In the group of patients with baseline CD4 50-199 cells $/ \mathrm{mm}^{3}$, most patients experienced a CD4 increase. 1 patient (Ny SA) died after four years of receiving ARV; her complications included diarrhea, IO conditions, TB, septic arthritis, meningoencephalitis, delirium and respiratory failure but no CD4 values were found in the period. In the group of patients with an initial CD4 cell count of 200-349 cells $/ \mathrm{mm}^{3}$, a total of thirteen $(34 \%)$ had a CD4 increase of $>500$ cells $/ \mathrm{mm}^{3}$ and none of these patients died or had worsening CD4 values. Of the fifteen patients who had an initial CD4 cell count of 200-349 there were six patients who increased their CD4 cell count to $>350$ cells $/ \mathrm{mm}^{3}$ and five patients who kept their CD4 values fixed in the 200-349 cells $/ \mathrm{mm}^{3}$ range. There was one patient who experienced a worsening clinical condition. This patient started antiretroviral therapy with Stage 4 conditions, with opportunistic infections of diarrhea, candidiasis, pneumonia and CD4 value of 207. The patients had been on medication for 8 months and the patient's compliance rate was low as patients often forgot to take medicine.

CD4 is the best parameter for measuring immunodeficiency, and can also be used as an early marker of virological failure in HIV patients. When used in conjunction with clinical judgment, CD4 can be an early indicator of disease progression because CD4 cell counts decline earlier than clinical conditions. Where possible there should be two CD4 test results below the threshold before the ARV is started..$^{4,10}$

The use of antiretroviral therapy allows for side effects, but each individual has an unequal response. Drug side effects can lead to deterioration of the patient's condition and decreased patient compliance. In this study, there were 55 incidence of antiretroviral side effects. There were seven patients experiencing gynecomastia and fifteen suffered severe headaches caused by the use of efavirenz. A cross-sectional study of ART cohort results in Malawi reported the prevalence of gynecomastia in men receiving antiretroviral drugs was $6 \%$. Studies show gynecomastia to be the fourth most common drug reaction associated with antiretroviral therapy between 2010 and 2014. ${ }^{11}$ Another side effect of efavirenz is interference with CNS. About 53\% of patients report CNS disorders or psychiatric disorders, such as mood disorders, nightmares and insomnia. ${ }^{12,13}$ Nevirapine causes side effects of skin rash, Stevens - Johnson Syndrome (SJS), jaundice, and hepatitis with frequencies of $2 \%, 2 \%, 9 \%$, and $4 \%$, respectively. Serious side effects of Nevirapine use include liver damage; as much as $18 \%$ was reported in Nigeria, with alongside symptoms of jaundice, gastric pain and fever(13). There were two patients who eventually died with the final diagnosis of drug induced hepatitis. Four mechanisms commonly underlie liver damage in HIVinfected patients to ARVs: (1) direct drug toxicity; (2) Hypersensitivity reactions with liver involvement; (3) mitochondrial toxicity; and (4) immune restoration in the presence of HBV or HCV infection. ${ }^{14}$ Tenofovir causes nausea and vomiting (1\%) and renal disorders $(1 \%)$, whereas stavudine causes peripheral neuropathy $(9 \%)$. twenty patients had anemia due to the use of zidovudine. On the use of Zidovudine there are cases of anemia about in $3 \%-12 \%$ in patients. Bone marrow suppression may cause anemia, and granulocytopenia occurs in patients with very low CD4 cell counts and greater doses of zidovudine. ${ }^{12,13}$ A weakened immune system makes the patient vulnerable to various types of opportunistic infections. 544 opportunistic infections can occur in HIV / AIDS patients with diarrhea, candidiasis and pulmonary TB being the most common. Ekwaru et al. ${ }^{15}$ concluded in their study that episodes of OI may decrease CD4 cell counts and have an effect on the increase in viral load in HIV-positive people receiving ARVs, so the prevention of OIs is absolutely vital.

\section{Conclusions}

From this study it can be concluded that those most commonly affected were male, age between $18-29$ year; $66 \%$ were married, and $75 \%$ had a steady job. Free sex behavior was responsible for the high heterosexual risk factors in patients. Most ARV regimens are Triple FDC. The use of antiretroviral drugs provides good results that can be observed in the improvement of clinical condition of patients, the increases in CD4 cell counts and the reduced OIs experienced by patients. Drug side effects, however can worsen a patient's condition.

\section{References}

1. Edward C. Klatt M. PATHOLOGY OF HIV / AIDS. J Gen Virol. 2017;91(PT 1):6-51.

2. King K. Holmes, MD, PhD, P. Frederick Sparling, MD, Walter E. Stamm, MD, Peter Piot, MD, PhD, Lawrence Corey, MD, Myron S. Cohen, MD D. Heather Watts, MD RAN. Sexually Transmitted Diseases. 4th ed. The McGraw-Hills Companies; 2008. 341-358 p.

3. Ditjen P2P Kementrian Kesehatan RI. Laporan Situasi Perkembangan HIVAIDS \& PIMS di Indonesia JuliSeptember 2016 [Internet]. Indonesian Ministry of Health. 2016. Available from: http://www.aidsindonesia. or.id/ck_uploads/files/Laporan HIV AIDS 2016 - Triwulan 3.pdf

4. Kementerian Kesehatan RI. Pedoman Pengobatan Antiretroviral. 2016;

5. Annison L, Dompreh A, Adu-Sarkodie Y. The immunological response of HIVpositive patients initiating HAART at the Komfo Anokye Teaching Hospital, Kumasi, Ghana. Ghana Med J [Internet]. 2013;47(4):164-70. Available from: /pmc/articles/PMC3961850/?report=ab stract

6. Avihingsanon A, Maek-a-nantawat W, Gatechompol S. International Journal of Infectious Diseases Ef fi cacy and safety of a once-daily single-tablet regimen of tenofovir, lamivudine, and efavirenz assessed at 144 weeks among antiretroviral-naïve and experienced HIV-1infected Thai adults \$, \$ \$. Int J Infect Dis [Internet]. 2017;61:89-96. Available from: http://dx.doi.org/10.1016/j.ijid.2017.06. 009

7. Kementerian Kesehatan Republik Indonesia - Direktorat Jenderal Pengendalian Penyakit dan Penyehatan 
Lingkungan. Pedoman Nasional Tatalaksana Klinis Infeksi HIV dan Terapi Antiretroviral pada Orang Dewasa. 2011. 75 p.

8. Tortora GJ, Case CL. Microbiology An Introduction. 10th ed. United States: Pearson; 2010. 487 and 542.

9. Wester CW, Kim S, Biostat D, Bussmann H, Avalos A, Ndwapi N, et al. Initial Response to Highly Active Antiretroviral Therapy in HIV-1C Infected Adults in a Public Sector Treatment Program in Botswana. 2005;40(3):336-43.

10. Badri M, Lawn SD, Wood R. Utility of CD4 cell counts for early prediction of virological failure during antiretroviral therapy in a resource-limited setting.
BMC Infect Dis. 2008;8(December 2006):1-8.

11. Singano V, Amberbir A, Garone D, Kandionamaso C, Msonko J, Van Lettow M, et al. The burden of gynecomastia among men on antiretroviral therapy in Zomba, Malawi. PLoS One. 2017;12(11):1-13.

12. Brunton L, Chabner B, Knollman B. Goodman and Gilman's The Pharmacological Basis of Therapeutics. Vol. 53, Journal of Chemical Information and Modeling. 2013. 1689$1699 \mathrm{p}$.

13. Eluwa GI, Badru T, Akpoigbe KJ. Adverse drug reactions to antiretroviral therapy (ARVs): Incidence, type and risk factors in Nigeria. BMC Clin
Pharmacol [Internet]. 2012;12(1):7. Available from: http://www.biomedcentral.com/1472-6904/12/7

14. Puoti M, Nasta P, Gatti F, Matti A, Prestini K, Biasi L, et al. HIV-related liver disease: ARV drugs, coinfection, and other risk factors. J Int Assoc Physicians AIDS Care. 2009;8(1):3042.

15. Ekwaru JP, Campbell J, Malamba S, Moore DM, Were W, Mermin J. The effect of opportunistic illness on HIV RNA viral load and CD4 â€ $€^{\mathrm{TM}} \mathrm{T}$ cell count among HIV-positive adults taking antiretroviral therapy. 2013;(May 2003):1-6. 